\title{
Damage Analysis and Evaluation of Light Steel Structures Exposed to Wind Hazards
}

\author{
Na Yang ${ }^{1,2, *}$ and Fan Bai ${ }^{1,2}$ \\ 1 School of Civil Engineering, Beijing Jiaotong University, Beijing 100044, China \\ 2 Beijing's Key Laboratory of Structural Wind Engineering and Urban Wind Environment, \\ Beijing 100044, China; 13115291@bjtu.edu.cn \\ * Correspondence: nyang@bjtu.edu.cn; Tel.: +86-10-5168-3956
}

Academic Editor: Zhong Tao

Received: 7 December 2016; Accepted: 20 February 2017; Published: 2 March 2017

\begin{abstract}
Compared to hot-rolled steel structures, cold-formed steel structures are susceptible to extreme winds because of the light weight of the building and its components. Many modern cold-formed steel structures have sustained significant structural damage ranging from loss of cladding to complete collapse in recent cyclones. This article first provides some real damage cases for light steel structures induced by the high winds. After that, the paper reviews research on the damage analysis and evaluation of light steel structures caused by strong winds, which include connection failure, fatigue failure, purlin buckling, and primary frame component instability problems. Moreover, this review will mention some applications of structure damage assessment methods in this area, such as vulnerability analysis and performance-based theory, etc.
\end{abstract}

Keywords: damage; light steel structures; cladding; purlin; wind hazards

\section{Introduction}

Compared to hot-rolled steel structures, cold-formed light steel structures are especially susceptible to extreme winds because of the light weight of the building and its components. It is observed many damage phenomenon in typhoons "Yun Na" [1], "Hgupit" [2,3], Cyclone Yasi, Cyclone Larry [4,5] and "Caihong" [6]. Many modern cold-formed steel structures had sustained significant structural damage ranging from loss of cladding and the buckling of the components to the complete collapse in recent cyclones.

As can be seen in Figure 1, the cladding-fastener connections were broken by strong wind. Moreover, the corrugated cladding profiles were torn by the wind after the cladding broken.
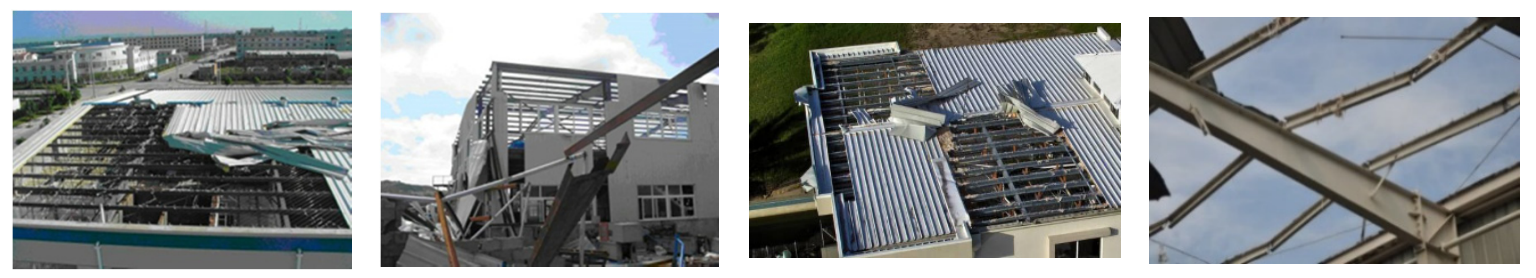

Figure 1. Failure of cladding-fastener connections.

As the second member to transfer the load from cladding to the main resisting frame, the $\mathrm{C} / \mathrm{Z}$ cold formed sections purlins were also vulnerable to strong wind. As can be seen in Figure 2, the purlins were buckled under wind uplift loading and the sheeting was also torn by the wind force in some cases. 

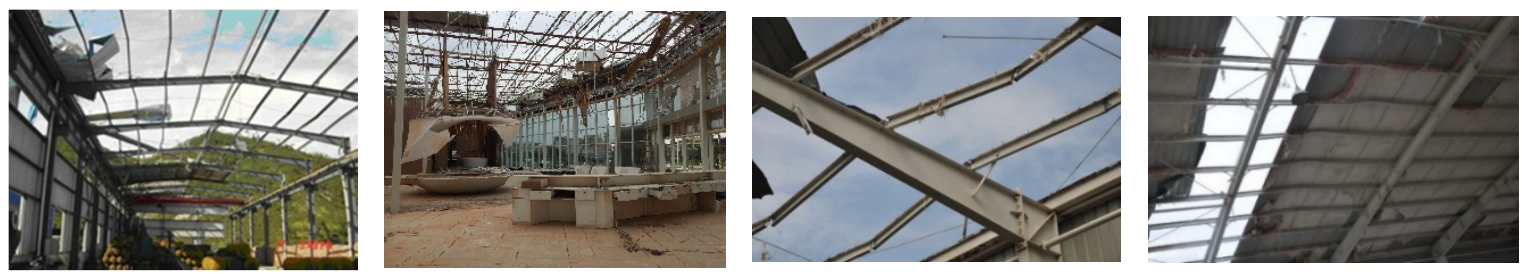

Figure 2. Buckling of Purlins under the wind uplift loadings.

The Figure 3 shows the main resisting frame collapsed during Typhoon "Caihong" [6] in Southeast of China. The beam of the frame buckled while most of its connection or purlins stayed safe during the hurricane event.

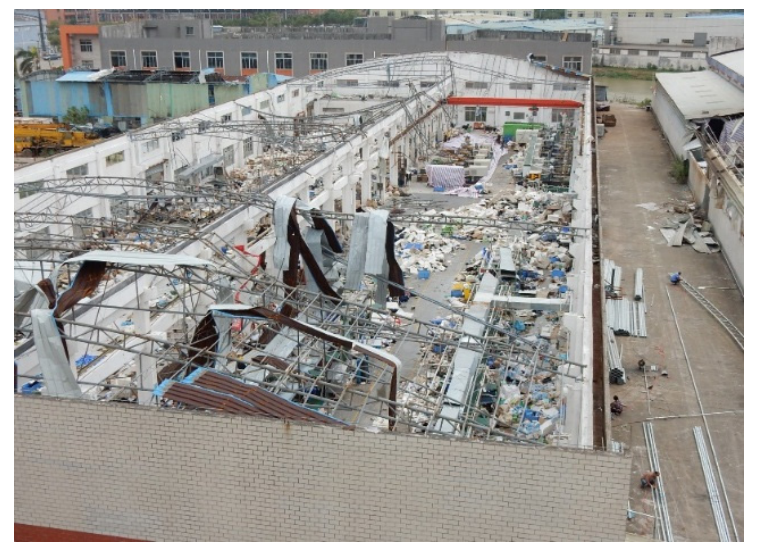

Figure 3. Mainframe collapsed during the typhoon event [6].

To solve these problems and provide practical solutions to avoid these types of damage, research has been conducted around the world for several decades, mainly concentrating on the performance of claddings under static and fatigue loadings, as well as buckling behavior of purlins under wind uplift loadings to the resisting capacity of the original resisting frame under wind uplift or lateral loads. However, from the aspect of wind hazard investigation on the light steel structures, detailed and careful work, such as the damage level of different components under different wind load, should be studied. Previous studies seem too general to make an accurate damage evaluation on light steel structures. Design and safety checks are performed for individual members, components, or connections based on simple assumptions of structure concepts. Therefore, it is hard to make a precise prediction of the real light steel structure systems under extreme wind loads.

\section{Cladding}

Profiled steel cladding is widely used in both roof and wall paneling. The cladding is fixed at its crest to battens or purlins beneath using self-tapping screws to prevent water ingress. The corrugated cladding is fixed at each alternate crest using a fastener comprising a self-tapping screw. Roofing of low-rise buildings (houses, warehouses, industrial sheds, etc.) are subjected to large temporally and spatially varying wind pressures during wind storms such as tropical cyclones. Theses fluctuating pressures are generated by turbulence in the approaching wind flow. The pressures on parts of the roof vary with the changes in wind speed and direction as a cyclone tracks past the building. Roof cladding with light gauge profiled metal sheeting are susceptible to low-cycle fatigue, as was seen in Darwin, Australia, after Cyclone Tracy in 1974, where more than $90 \%$ of houses and $70 \%$ of other structures suffered significant loss of roof cladding. Following Cyclone Larry, which impacted on Innisfail, Australia, in 2006, some cases of fatigue failure of metal cladding were also observed [5]. 
When subjected to strong sustained fluctuating wind uplift, the sheeting may fail locally in the vicinity of fasteners by cracking induced by fatigue $[7,8]$. These cracks can be propagated to form a sizeable hole that allows the fastener to pull through the cladding sheet, potentially expediting the loss of entire cladding sheets. Loss of roofing sheets could then lead to the overloading of other structural elements, with the consequence often being the collapse of the entire building.

As a first step to study the fatigue behavior of light gauge corrugated steel roofing under cyclic uplift wind loading, experimental and finite element analyses of roofing assemblies with different spans and fastening systems were conducted under static loading conditions.

$\mathrm{Xu}$ and Teng [9] proposed the finite element method to study the collapse and local plastic behavior of trapezoidal profile sheeting under monotonic loads. The close agreement between finite element and test results validated the finite element model and open the way for a theoretical model of the failure behavior of roofing sheets. Mahendran [10-12] proposed several test methods for profiled steel cladding system and conducted full size and small scale experiments, in which they investigated the influence of secondary elements, the thickness of plates, and yield limit, as well as the geometrical properties of the screw. They also described the behavior and the design of crest-fixed profiled steel roof claddings under wind uplift, and came to the conclusion of two different local failure modes: the dimpling of crests/pull-through failure at the fastener [10]. Research by Mahaarachchi and Mahendran [13] concluded that the use of two-span specimens in the longitudinal direction with simple supports and one or two panels in the transverse direction were adequate when simulating real behavior, whether it is investigated in a laboratory or through analytical models. Lovisa et al. [14] developed a numerical model that can simulate the static response of corrugated roof claddings. The model can be used to predict the response of cladding subject to design cyclone pressure trace, excluding fatigue effects, and demonstrates the potential of the model to investigate more complicated loading circumstances. Mahendran $[15,16]$ proposed a finite element model that includes a splitting criterion and other advanced features (including geometric imperfections, buckling effects, contact modeling, and hyperelastic behavior of neoprene washers) that used a detailed parametric study to develop suitable design formulae for local failures. Stephan [17] investigated a testing approach for trapezoidal crest fastened metal claddings that may serve as a basis for testing research of the cladding systems.

As to research on the fatigue problem of cladding-fastener connections, Morgan and Beck [18] and Beck and Stevens [19] first investigated the possibility of wind-induced fatigue damage to screw-fastened light-gauge-steel roofing sheets. They conducted a series of fatigue tests in laboratories and concluded that fatigue failure in the vicinity of fasteners is the only possible cause of the severe roofing damage during Cyclone Tracy. The research conducted by Lynn and Stathopoulus [20] also highlighted the importance of wind-induced fatigue damage to metal buildings. Mahendran [21-24] performed a large number of fatigue tests on the arctangent type of roofing sheets with different spans and fastening systems under constant amplitude repeated loads. The tests were conducted by controlling the total fastener reaction force at the central support. Ellifritt and Burnette [25] carried out some tests on the trapezoidal type of sheets and made reports on tests with similar objectives for cladding with the trapezoidal cross section. Xu [26,27] carried out tests on three types of metallic plates commonly used in Australia to evaluate the effect of cyclic loads of constant amplitude and loads that simulated the lifting of the roof due to negative pressures exerted by the wind.

It is shown in this research that the fatigue behavior of the joints was related to the wind-induced local plastic deformation (LPD) [28] in the form of nuts below the node hole around the plate of local depression. Changes in the geometrical dimensions of the profiled steel plate (wave height, wave pitch, etc.) affect the LPD strength and fatigue properties of corrugated steel roof joints. The addition of wind-resistant gaskets at the joints increases the effective wind-resistant area beneath the nuts, delaying the occurrence and expansion of cracks and plastic deformation, and increasing the LPD strength of the joints. 
From the view of the initiation and propagation of fatigue cracks, $\mathrm{Xu}$ [27] studied the constant-amplitude fatigue problem of the corrugated steel roof commonly used in Australia and found that the fatigue cracks growth pattern will be different under different cyclic loading levels. The fatigue test of Mahendran [21] reflects the effect of cyclic load amplitude on the fatigue performance of the joint from the viewpoint of the number of pre-failure load cycles. The discreteness of this result is the interaction of material properties, nodal fixation degree, and node fixed position. Lovisa et al. [7] described the mechanism underlying the fatigue behavior by studying the initiation of cracking in corrugated high strength steel cladding. In combination with detailed stress analysis, such criteria could be implemented in a numerical model to predict crack initiation in cladding. The model can provide an analytical tool that could greatly assist the fatigue design process and lead to a reduction in the total reliance on prototype testing of each system used.

$\mathrm{Xu}$ et al. $[26,27]$ studied the fatigue behavior of three types of profiled steel sheets, which are commonly used in Australia, using the double-slab model. They found that the plate type has an effect on the fatigue damage accumulation. The anti-fatigue ability of corrugated a steel roof is higher than that of a ribbed steel roof under low amplitude cyclic loading. The fatigue capacity of a ribbed steel roof is higher than that of a corrugated steel roof under high amplitude cyclic loading. Mahendran [21-24] studied the fatigue properties of the trapezoidal steel roof commonly used in Australia and found that the fatigue resistance of the trapezoidal steel roof is better than the corrugated steel roof. For the corrugated steel roof, the stiffness of the node was reduced and the fatigue crack propagation speed was accelerated by the large load cycle, which leads to premature fatigue failure. In the case of the trapezoidal steel roof, local depressions occur at the node due to the larger load cycle, but this deformation would produce a strong thin film effect, which increased the stiffness of the joint and delayed fatigue crack propagation. Therefore, the trapezoidal steel roof subjected to higher amplitude cyclic loads at the early stage of the storm would delay the occurrence of fatigue failure under strong wind loading. Though the research of the previous work focused on the static and fatigue problem of the cladding system, both of these two problems have been studied successfully and the failure mode for both load conditions has been clarified. However, the fatigue microcrack initiation process and the residual bearing capacity of the connection after wind-induced fatigue in different levels are still unknown to researchers. There are still some problems in need of solutions for the evolution of crack damage, as well as the relationship between fatigue damage with the wind load level, as well as the cyclic duration.

\section{Purlin-Sheeting System (Roof/Wall Systems)}

Research of girt and purlin design for wind loads has been investigated for over 50 years. For building structural systems, purlin is a type of secondary element acting as an intermediate member to transfer load from the roof sheeting to the primary frame structure. Common types of purlin sections include channel, zed, and sigma shapes. The open and thin-walled cross section may lead to a high susceptibility to various types of buckling failure, such as local, distortion, and lateral torsional buckling. Roof sheeting, which is normally attached to purlins using self-drilling screws, can enhance a purlin's load resistance by supplying it with a certain degree of lateral and rotational restraining effect. Hancock and Trahair $[29,30]$ concluded that the restraints of sheeting to the purlins included four different types of restraining actions: minor axis deflection, minor axis rotation, axial rotation, and warping of the member. The lateral buckling of purlins with diaphragm restraints was studied using finite element analysis. The results show that the effectiveness of diaphragm restraints depends not only on their stiffness but also on their height above the shear center axis of the purlin, and the buckling resistance is significantly increased when the loads act below the shear center. Rousch and Hancock [31,32] also proposed a non-linear analysis model that could provide nonlinear response data for screw-fastened purlins under wind uplift loading. Moreover, several experimental tests for both bridged and unbridged Z- and C-section purlins under uplift loads were compared with the model. Lucas et al. $[33,34]$ developed both full and simplified models to study the interaction between the 
sheeting and purlins using finite element methods. It is found that the simplified model can account for the cross-sectional distortion of the purlin, the shear and rotational restraining effects of the sheeting, and failure of the purlin by local buckling or yielding.

Research has continued to focus on validation of the rotational stiffness. Katnam and Kujawa [35] proposed a nonlinear finite element model to estimate the rotational restraint provided by sandwich sheeting. Moreover, the model could be used for parametric studies to investigate the influencing factors. Based on the study of the redistribution of contact forces as a function of loading, Vrany [36] proposed an analytical model that can be used for solving the Z-shaped and C-shaped purlins for both gravity and uplift loading. Design codes like EC3 [37] also provided this approach to get the real rotational stiffness of the purlin. Gao and Yang [38,39] both provided a more precise semi-analytical model to calculate the rotational stiffness of the purlin.

For the effect of the restraint effect on the pre-buckling, buckling, or post-buckling behavior of the purlins, Ye et al. [40,41] studied the influence of diaphragm restraints on the bending, local, and distortion buckling behavior of roof purlins. Li [42-46] proposed a series of models to predict pre-buckling stress and buckling types such as local, distortion, and global buckling ability of the partially restrained C-section and Z-section purlins subjected to uplift loadings. Basaglia and Dinar [47-49] also conducted some tests on the behavior of purlins and applied the GBT theory into the research of purlin-sheeting systems. After Polyzois [50] had studied the effect of the sag rods on the buckling limit of the purlins, Zhang and Tong [51-55] proposed a theory to analysis the stress and lateral buckling problem of purlins with the top flange horizontally restrained and with one anti-sag bar at middle span sections. Hancock and Pham [56] extended the Direct Strength Method into the purlin design. Due to the flexibility of the rotational stiffness, they proposed the rotational stiffness as zero, which induced a result that the method was too conservative. Gaorgescu [57] studied the stabilization of continuous Z-purlins by sandwich panels through an experimental approach. Ren $[58,59]$ conducted research on the pre-buckling analysis of C- and Z-section purlins under wind uplift considering partially restraint. Gosowski [60] also made an analysis on the laterally restraint cold-formed C-section purlins according to the Vlasov theory without considering the stability problem. Vireira [61] proposed a simplified model to predict the longitudinal stresses in C-section purlins under uplift loadings. Combined with the R-factor method, Gao and Moen [62] also extended the Direct Strength Method (DSM) to the purlin-sheeting systems design. Through modifying the coefficient of the DSM method, Ren [63] extended the DSM method into the buckling design of partially restrained $\mathrm{Z}$ section purlins with the results calculated from the finite element method.

It can be seen from previous studies that the frame work about pre-buckling stress distributions and buckling limit states of the purlins has been established. However, the effect and sensitivity of the restraint from the sheeting to the strength limit states on the purlins still have some problems to be studied, such as the screw locations and the torque induced by the restraint that can cause pull through failure on the screw connections. The extended DSM method for the purlin under different loading such as shear force, localized loading may also need to be studied. Moreover, the damage assessment such as the strength or bending stiffness reduction could also be one new research point to be analyzed.

\section{Main Resisting System}

The main force member of the light steel structure of the portal frame is mainly composed of $\mathrm{H}$-shaped steel or a cold-formed thin-walled button-back combination component. The interaction with the envelope will have a great impact on its wind resistance. Among them, the lateral support of the P-S system to the main bearing member increases the anti-stability under the wind load. Davis [64] and Mhandran [65] proposed two equivalent models to describe the significant interactions between the main force member and the roof system. However, the current research results mainly focus on the traditional hot-rolled H-beam members and do not consider the reduction of the P-S system's restraining effect after the damage. For the cold-formed thin-walled buckle combination components 
with more applications in recent years, there is still a lack of understanding of the purlin-sheeting system interaction mechanism.

Jang [66], Duthinh [67], and Simiu [68] calculated the wind-resistant ultimate bearing capacity of the portal frame based on the data from the wind tunnel test data of the low-rise light steel structure and the American code. They proposed a working definition of "failure" for steel structures using nonlinear finite-element analysis and presented a methodology for nonlinear structural behavior and the directionality of the wind speeds.

Based on the wind tunnel test data, Li [69] studied the initial defect on the damage shape and the plastic damage of the joints without buckling for China's southeastern coastal light steel frame. Compared to the component-level study, it can be seen that little research has been done at the structure level. The interactions between different systems and the damage sequence for the whole structure levels under different directionality wind and different limit states work on different component or system levels need to be checked in future research.

\section{Performance Evaluation of Light Steel Systems Exposed to Wind Hazards}

Fragility analysis methodology was the most common method for implementing the performance-based engineering theory into the evaluation of light steel systems exposed to wind hazards since it is widely applied in the evaluation of the low-rise light-frame wood construction exposed to multi-hazard loads. Its main theory was mentioned as below.

Fragility can be defined as the conditional probability of failure of a structural member of the system for a given set of input variables. It is expressed as

$$
P[L S]=\sum_{\text {all } D} P[L S \mid D=x] P[D=x],
$$

in which $D=a$ random demand on the system (e.g., 3 s gust wind speed); $P[L S \mid D=x]$ is the conditional probability of the limit state (LS) at given demand $x$. The hazard is defined by the probability $P[D=x]$. The conditional probability, $P[L S \mid D=x]$ is the fragility. Equation (2) also can be expressed in convolution integral form if the hazard is a continuous function of demand $x$ :

$$
P[L S]=\int_{0}^{\infty} F r(x) g_{X}(x) d x
$$

in which $\operatorname{Fr}(x)=$ fragility function of demand $x$ expressed in the form of a probability density function. The conditional probability $\operatorname{Fr}(x)$ is known as a "fragility" [70]. In order to study the fragility of the each level of light-frame structures, several types of research have been conducted. Garcia [71] established a probabilistic analysis framework for the vulnerability of typical light steel structures in the United States. Ellingwood [72-75] proposed a series of fragility analysis methodologies for assessing the response of light-frame wood construction exposed to stipulated extreme windstorms and earthquakes. Henderson and Ginger [76,77] proposed a series of vulnerability model for Australian high-set house or metal-clad industrial buildings to extreme wind loading for cyclonic regions. Lee and Rosowsky [78] presents a fragility assessment for roof sheathing in light frame constructions built in high wind regions which considering the influence factor of roof shapes, geographic locations, nail types, and exclosure conditions. The fragility model can be used to develop performance-based design guidelines for wood frame structures as well as tools for condition assessment and loss estimation for use with the existing building inventory. Zhao and $\mathrm{Gu}$ [79] proposed a method of probabilistic wind vulnerability analysis for typical light-weight steel buildings in China. Based on real damage investigation of light steel industrial buildings, Song [3] and Xiao [80] studied the damage of light steel structures under typhoon loads through the fragility method. Goyal and Datta [81] presented a methodology to assess the effect of wind directionality on the vulnerability of rural houses to cyclonic wind speed and also provide a cyclonic risk assessment of coastal regions. Sivapathasundaram and Mahendran [82] developed fragility curves for localized pull-through failures of thin steel roof 
battens. The proposed model can be used to evaluate the effects of roof batten span and spacing and levels of enhancement that could be achieved with the strengthening method proposed for roof battens. Zhang [83] studied the typhoon-induced wind vulnerability for residential buildings in Japan based on reliability modelling. However, performance-based wind engineering methodologies for cold-formed light-frame steel construction are currently unavailable. Performance goals, vulnerable model, time-dependent theory, and limit states suitable for cold-formed steel structural systems exposed to wind hazard to incorporate different owner and occupant performance expectations still need to be studied.

\section{Conclusions}

Cold-formed light steel structures are especially susceptible to extreme winds because of the light weight of the building and its components. Research on this topic has been conducted around the world for several decades. There are still some problems that need to be further studied on limit states about claddings, purlins, and mainframes. Moreover, it is necessary to make a precise prediction for the response of real light steel structures under extreme wind loads. For cladding connections, previous studies only focused on the static and fatigue performance of the screw connection. However, the evolution of crack damage and the degradation or deterioration of connections induced by fatigue could be next research point. For purlin sheeting systems, previous research concentrated on the stress distribution of pre-buckling and limit states of buckling for purlins. The sensitivity of restraint to the limit states of the purlins the damage assessment such as strength or bending stiffness reduction could also be a new research point to be analyzed. For the light steel structure frames, previous literature presents some work on understanding the interactions between cladding support and main resistant frames. As a result, it is crucial for advancing cold-formed steel design to the next stage. Performance-based wind engineering methodologies for cold-formed light-frame steel construction are currently unavailable. Performance goals, limit states levels, time-dependent reliability theory, and fragility analysis for the cold-formed steel structural systems exposed to wind hazard could also be the significant research points to be studied in the future.

Acknowledgments: This research is supported by the National Natural Science Foundation of China for Excellent Young Scholars (51422801) and the Beijing Natural Science Foundation of China (Key Program, 8151003).

Author Contributions: Na Yang conceived and designed the framework of the whole manuscipt, Fan Bai collected all the literatures or references for the review.

Conflicts of Interest: The authors declare no conflict of interest.

\section{References}

1. Pan, S.; Shi, Y.Z.; Geng, X.Q. Damage analysis of light steel industrial building under 0414 Typhoon of Taizhou, Zhejiang. Steel Struct. 2005, 20, 52-57. (In Chinese)

2. Jin, Y.; Yang, Q.; Li, Q. Typhoon damage investigation of claddings of light steel buildings. J. Build. Struct. 2010, 2, S197-S201. (In Chinese)

3. Song, F.F. Typhoon Damage Estimation and Prediction of Wind Vulnerable Stuctures; Harbin Institute of Technology: Harbin, China, 2010. (In Chinese)

4. Boughton, G.N.; Henderson, D.J.; Ginger, J.D.; Holmes, J.D.; Walker, G.R.; Leitch, G.J.; Somerville, L.R.; Frye, U.; Jayasinghe, N.C.; Kim, P.Y. Tropical Cyclone Yasi Structural Damage to Buildings; CTS Technical Report No. 57; James Cook University: Townsville City, Australia, 2011; Volume 4.

5. Henderson, D.; Ginger, J.; Leitch, C.; Boughton, G.; Falck, D. Tropical Cyclone Larry Damage to Buildings in the Innisfail Area; Technical Report No. 51; James Cook University: Townsville City, Australia, 2006; Volume 9.

6. Fan, B.Y.; Tamura, S.Y.; Cao, Q.S.; Yang, N. Investigation and Analysis of Public and Industrial Building Damage Caused by Typhoon “Mujigae”. In Zhanjiang Guangdong Yearbook of Disaster Prevention; Zhanjiang Municipal People's Government: Zhanjiang, China, 2016. (In Chinese)

7. Lovisa, A.C.; Henderson, D.J.; Ginger, J.D.; Walker, G. Characterizing fatigue microcrack initiation in profiled steel roof cladding. Eng. Struct. 2016, 125, 364-373. [CrossRef] 
8. Xu, Y.L. Fatigue performance of screw-fastened light-gauge-steel roofing sheets. Eng. Struct. 1995, 121, 389-398. [CrossRef]

9. Xu, Y.L.; Teng, J.D. Local plastic failure of light gauge steel roofing sheets: Finite element analysis versus experiment. J. Constr. Steel Res. 1994, 30, 125-150. [CrossRef]

10. Mahendran, M. Behaviour and design of crest-fixed profiled steel roof claddings under wind uplift. Eng. Struct. 1994, 16, 368-376. [CrossRef]

11. Mahendran, M. Test method for determination of pull-through strength of screwed connections in profiled steel claddings. Civ. Eng. Trans. 1995, 37, 219-227.

12. Mahendran, M. Wind-resistance low-rise buildings in the Tropics. J. Perform. Constr. Facil. 1995, 9, $330-345$. [CrossRef]

13. Mahaarachchi, D.; Mahendran, M. Strength of screwed connections in crest-fixed trapezoidal steel claddings. Aust. J. Struct. Eng. 2005, 6, 11-23.

14. Lovisa, A.C.; Wang, V.Z.; Henderson, D.J.; Ginger, J.D. Development and validation of a numerical model for steel roof cladding subject to static uplift loads. Wind Struct. 2013, 17, 495-513. [CrossRef]

15. Mahaarachchi, D.; Mahendran, M. Wind uplift strength of trapezoidal steel cladding with closely spaced ribs. J. Wind Eng. Ind. Aerodyn. 2009, 97, 140-150. [CrossRef]

16. Mahaarachchi, D.; Mahendran, M. A strain criterion for pull-through failures in crest-fixed steel claddings. Eng. Struct. 2009, 31, 498-506. [CrossRef]

17. Stephan, H.C. Investigation of a Testing Approach for Trapezoidal Crest Fastened Metal Cladding; Stellenbosch University: Stllenbosch, South Africa, 2013.

18. Morgan, J.; Beck, V. Failure of sheet metal roofing under repeated wind loading. Civ. Eng. Trans. 1977, 138, 290-294.

19. Beck, V.; Stevens, L. Wind loading failures of corrugated roof cladding. Civ. Eng. Trans. 1979, 19, 1-5.

20. Lynn, B.A.; Stathopoulos, T. Wind-induced fatigue on low metal buildings. J. Struct. Eng. 1985, 111, 826-839. [CrossRef]

21. Mahendran, M. Fatigue behavior of corrugated roofing under cyclic wind loading. Civ. Eng. Trans. 1990, 32, 219-226.

22. Mahendran, M. Effect of Overload Cycles on Thin steel roof claddings during cyclonic winds. J. Test. Eval. Am. Soc. Test. Mater. 1994, 22, 451-457.

23. Mahendran, M. Steel roof claddings under simulated cyclonic wind forces. Aust. Civ. Eng. Trans. 1994, 36, 1-10.

24. Mahendran, M. Towards an appropriate fatigue loading sequence for roof claddings in cyclone prone areas. Eng. Struct. 1995, 17, 476-484. [CrossRef]

25. Ellifrit, D.; Burnette, R. Pull-over strength of screws in simulated building tests. In Proceedings of the Tenth International Speciality Conference on Cold-formed Steel Structures, St. Louis, MI, USA, 23-24 October 1990.

26. Xu, Y.L. Determination of wind-induced fatigue loading on roof cladding. J. Eng. Mech. 1995, 121, $956-963$. [CrossRef]

27. Xu, Y.L. Wind-induced fatigue loading and damage to hip and gable roof claddings. J. Struct. Eng. 1996, 122, 1475-1483. [CrossRef]

28. Henderson, D.J. Response of Pierced Fixed Metal Roof Cladding to Fluctuating Wind Loads; School of James Cook University: Townsville, Australia, 2010.

29. Hancock, G.J.; Trahair, N.S. Finite element analysis of the lateral buckling of continuously restrained beam-columns. Civ. Eng. Trans. 1978, 20, 120-127.

30. Hancock, G.J.; Trahair, N.S. Lateral buckling of roof purlins with diaphragm restraints. Civ. Eng. Trans. 1979, $21,10-15$.

31. Hancock, G.J.; Celeban, M.; Healy, C.; Geogiou, P.N.; Ings, N.L. Tests of purlins with screw fastened sheeting under wind uplift. In Proceedings of the Tenth International Speciality Conference on Cold-formed Steel Structures, St. Louis, MI, USA, 23-24 October 1990.

32. Rousch, C.J.; Hancock, G.J. Comparison of tests of bridged and unbridged purlins with a nonlinear analysis model. J. Constr. Steel Res. 1997, 41, 197-220. [CrossRef]

33. Lucas, R.M. Modeling of cold-formed purlin-sheeting systems-Part 1: Full model. Thin-Walled Struct. 1997, 27, 223-243. [CrossRef]

34. Lucas, R.M. Modeling of cold-formed purlin-sheeting systems-Part 2: Simplified model. Thin-Walled Struct. 1997, 27, 263-286. [CrossRef] 
35. Katnam, K.B.; van Impe, R.; Lagae, G.; de Strycker, M. A theoretical numerical study of the rotational restraint in cold-formed steel single purlin-sheeting systems. Comput. Struct. 2007, 85, 1185-1193. [CrossRef]

36. Vrany, T. Effect of loading on the rotational restraint of cold-formed purlins. Thin-Wall Struct. 2007, 44, 1287-1292. [CrossRef]

37. European Committee for Standardization. Eurocode3: Design of Steel Structures Part 1-3, General Rules for Cold-Formed Thin Gauge Members and Sheeting; European Committee for Standardization (CEN): Brussels, Belgium, 2003.

38. Gao, T.; Moen, C. Predicting rotational restraint provided to wall girts and roof purlins by through-fastened metal panels. Thin-Walled Struct. 2012, 61, 145-153. [CrossRef]

39. Zhao, C.X.; Yang, J.; Wang, F.; Chan, A.H.C. Rotational stiffness of cold-formed steel roof purlin-sheeting connections. Eng. Struct. 2014, 59, 284-297. [CrossRef]

40. Ye, Z.M.; Kettle, R.; Li, L.; Schafer, B.W. Buckling behavior of cold-formed zed-purlins partially restrained by steel sheeting. Thin-Walled Struct. 2002, 20, 853-864. [CrossRef]

41. Ye, Z.M.; Kettle, R.; Li, L. Analysis of cold-formed zed-purlins partially restrained by steel sheeting. Comput. Struct. 2004, 82, 731-739. [CrossRef]

42. Chu, X.T.; Ye, Z.M.; Kettle, R.; Li, L.Y. Buckling behavior of cold-formed channel sections under uniformly distributed loads. Thin-Walled Struct. 2005, 43, 531-542. [CrossRef]

43. Li, L.Y. Lateral-torsional buckling of cold-formed zed-purlins partial-laterally restrained by metal sheeting. Thin-Walled Struct. 2004, 42, 995-1011. [CrossRef]

44. Yuan, W.B.; Cheng, S.S.; Li, L.Y.; Kim, B. Web-flange distortional buckling of partially restrained cold-formed steel purlins under uplift loading. Int. J. Mech. Sci. 2014, 89, 476-481. [CrossRef]

45. Li, L.Y. Analyses of distortional buckling of cold-formed sigma purlins using EN 19930103. J. Constr. Steel Res. 2009, 65, 2099-2102. [CrossRef]

46. Chen, J.-K.; Li, L.Y. Distortional buckling of cold-formed steel sections subjected to uniformly distributed transverse loading. Int. J. Struct. Stab. Dyn. 2010, 10, 1017-1030. [CrossRef]

47. Basaglia, C.; Camotim, D.; Goncalves, R.; Graca, A. GBT-based assessment of the buckling behavior of cold-formed steel purlins restrained by sheeting. Thin-Walled Struct. 2013, 72, 217-229. [CrossRef]

48. Basaglia, C. On the structural behavior of steel purlin-sheeting systems. Master's Thesis, University of Sao Paulo, Sao Calos, Brazil, 2004. (In Portuguese)

49. Dubina, D.; Ungureanu, V. Behaviour of multi-span cold-formed Z-purlins with bolted lapped connections. Thin-Walled Struct. 2010, 48, 866-871. [CrossRef]

50. Polyzois, D. Sagrods as lateral supports for girts and purlins. J. Struct. Eng. 1987, 113, 1521-1531. [CrossRef]

51. Zhang, L.; Tong, G. Moment resistance and flexural rigidity of lapped connections in multi-span cold-formed Z-purlin systems. Thin-Walled Struct. 2008, 46, 551-560. [CrossRef]

52. Zhang, L.; Tong, G.S. Stress analysis on cold-formed C-purlins subjected to wind suction load considering the effective stiffness of anti-sag bar. Thin-Walled Struct. 2015, 90, 107-118. [CrossRef]

53. Zhang, L.; Tong, G.S. Lateral buckling of simply supported C- and Z-section purlins with top flange horizontally restrained. Thin-Walled Struct. 2016, 99, 155-167. [CrossRef]

54. Zhang, L.; Tong, G.S. Lateral buckling of C-section purlins with one anti-sag bar at middle span section. Thin-Walled Struct. 2016, 102, 246-257. [CrossRef]

55. Sun, K.Q.; Tong, G.S.; Zhang, L. Twisting about constrained line of parallel purlins inter braced by sagrods under wind suctions. Thin-Walled Struct. 2016, 108, 30-40. [CrossRef]

56. Pham, C.H.; Hancock, G.J. Direct strength design of cold-formed purlins. J. Struct. Eng. 2009, 135, $229-238$. [CrossRef]

57. Gaorgescu, M.; Ungureanu, V. Stabilisation of continuous Z-purlins by sandwich panels: Full scale experimental approach. Thin-Walled Struct. 2014, 81, 242-249. [CrossRef]

58. Ren, C.; Li, L.Y.; Yang, J. Bending analysis of partially restrained channel-section purlins subjected to up-lift loadings. J. Constr. Steel Res. 2012, 72, 254-260. [CrossRef]

59. Li, L.Y.; Ren, C.; Yang, J. Theoretical analysis of partially restrained zed-purlin beam subjected to up-lift loads. J. Constr. Steel Res. 2012, 70, 273-279. [CrossRef]

60. Gosowski, B.; Kubica, E.; Rykaluk, K. Analysis of laterally restrained cold-formed C-shaped purlins according to Vlasov theory. Arch. Civ. Mech. Eng. 2015, 15, 456-468. [CrossRef] 
61. Vieira, L.C.M., Jr.; Malite, M.; Schafer, B.W. Simplified models for cross-section stress demands on C-section purlins in uplift. Thin-Walled Struct. 2010, 48, 33-41. [CrossRef]

62. Gao, T.; Moen, C.D. Extending the direct strength method for cold-formed steel design to through-fastened simple span girts and purlins with laterally unbraced compression flanges. J. Struct. Eng. 2014, 104, 1299-1328. [CrossRef]

63. Ren, C.; Zhao, X.Z.; Chen, Y.Y. Buckling behavior of partially restrained cold-formed steel zed purlins subjected to transverse distributed uplift loading. Eng. Struct. 2016, 114, 14-24. [CrossRef]

64. Davies, J.M.; Bryan, E.R. Manual of Stresses Skin Diaphragm Design; Granada Publishing: Great Britain, UK, 1982.

65. Mahendran, M.; Moor, C. Three-dimensional modeling of steel portal frame buildings. J. Struct. Eng. 1999, 125, 870-878. [CrossRef]

66. Jang, S. Evaluation of Ultimate Strength of Low-Rise Steel Building Frames and Components Using Wind Tunnel Data; Lehigh University: Bethlehem, PA, USA, 2004.

67. Duthinh, D.; William, P.F. Safety evaluation of low-rise steel structures under wind loads by nonlinear database-assisted technique. J. Struct. Eng. 2007, 133, 587-594. [CrossRef]

68. Duthinh, D.; Main, J.A.; Wright, A.P.; Simiu, E. Low-rise steel structures under directional winds: Mean recurrence interval of failure. J. Struct. Eng. 2008, 134, 1383-1388. [CrossRef]

69. Li, X.; Chen, S.F. Wind-resistant safety analysis of light-weight steel portal frame structures. J. Zhejiang Univ. 2013, 47, 2141-2145.

70. Ellingwood, B.R. Structural reliability and performance-based engineering. Struct. Build. 2008, 161, $199-208$. [CrossRef]

71. Garcia, P.A. Estimacion de Danos Producidos Por Viento en Edificaciones Industrials; Department of Civil Engineering, University of Puerto Rico: Mayaguez, Puerto Rico, 2008; pp. 44-48.

72. Ellingwood, B.R.; Rosowsky, D.V.; Li, Y.; Kim, J.H. Fragility assessment of light-frame wood construction subjected to wind and earthquake hazards. J. Struct. Eng. 2004, 130, 1921-1930. [CrossRef]

73. Ellingwood, B.R.; Tekie, P.B. Wind load statistics for probability-based structural design. J. Struct. Eng. 1999, 125, 453-463. [CrossRef]

74. Li, Y.; Ellingwood, B.R. Hurricane damage to residential construction in the US: Importance of uncertainty modeling in risk assessment. Eng. Struct. 2006, 28, 1009-1018. [CrossRef]

75. Li, Y.; Ellingwood, B.R. Framework for multihazard risk assessment and mitigation for wood-frame residential construction. J. Struct. Eng. 2009, 135, 159-168. [CrossRef]

76. Henderson, D.J.; Ginger, J.D. Vulnerability model of an Australian high-set house subjected to cyclonic wind loading. Wind Struct. 2007, 10, 269-285. [CrossRef]

77. Konthesingha, K.M.C.; Stewart, M.G.; Ryan, P.; Ginger, J.; Henderson, D. Reliability based vulnerability modeling of metal-clad industrial buildings to extreme wind loading for cyclonic regions. J. Wind Eng. Ind. Aerodyn. 2015, 147, 176-185. [CrossRef]

78. Lee, K.H.; Rosowsky, D.V. Fragility assessment for roof sheathing failure in high wind regions. Eng. Struct. 2005, 27, 857-868. [CrossRef]

79. Zhao, M.W.; Gu, M. Probabilistic wind vulnerability analysis of light-weight steel buildings. J. Cent. South Univ. 2012, 43, 3609-3618.

80. Xiao, Y.F. Typhoon Wind Hazard Analysis Based on Numerical Simulation and Fragility of Light-Gauge Steel Structure in Southeast China Costal Regions; Harbin Institute of Technology: Harbin, China, 2011. (In Chinese)

81. Goyal, P.K.; Datta, T.K. Effect of wind directionality on the vulnerability of rural houses due to cyclonic wind. Nat. Hazards Rev. 2013, 14, 258-267. [CrossRef]

82. Sivapathasundaram, M.; Mahendran, M. Development of fragility curves for localized pull-through failures of thin steel roof battens. Eng. Struct. 2016, 124, 64-84. [CrossRef]

83. Zhang, S.; Nishijima, K.; Maruyama, T. Reliability-based modeling of typhoon induced wind vulnerability for residential buildings in Japan. J. Wind Eng. Ind. Aerodyn. 2014, 124, 68-81. [CrossRef]

(C) 2017 by the authors. Licensee MDPI, Basel, Switzerland. This article is an open access article distributed under the terms and conditions of the Creative Commons Attribution (CC BY) license (http:/ / creativecommons.org/licenses/by/4.0/). 